\title{
MicroRNA-205 directly targets Krüppel-like factor 12 and is involved in invasion and apoptosis in basal-like breast carcinoma
}

\author{
BING GUAN $^{1}$, QING LI $^{2 *}$, LI SHEN $^{3 *}$, QIU RAO $^{4}$, YAN WANG $^{5}$, YUN ZHU $^{6}$, \\ XIAO-JUN ZHOU ${ }^{4}$ and XIAO-HONG $\mathrm{LI}^{1}$
}

\begin{abstract}
${ }^{1}$ Department of Pathology, Shanghai 6th People's Hospital Jinshan Branch, Shanghai 201599; ${ }^{2}$ Department of Pathology, Shanghai Pudong New Area People's Hospital, Shanghai 201299; ${ }^{3}$ Department of Cardiothoracic Surgery, Shanghai Children's Hospital, Shanghai 201040; ${ }^{4}$ Department of Pathology, Nanjing Jinling Hospital, Nanjing, Jiangsu 210002; ${ }^{5}$ Department of Pathology, The Second Affiliated Hospital with Nanjing Medical University, Nanjing, Jiangsu 210000; ${ }^{6}$ Department of Pathology, Jiangsu Province People's Hospital, Nanjing, Jiangsu 210029, P.R. China
\end{abstract}

Received March 31,2016; Accepted May 23, 2016

DOI: 10.3892/ijo.2016.3573

\begin{abstract}
We investigated microRNAs (miRs) specific to its target gene and exerting distinct biological functions for basal-like breast carcinoma (BLBC). Total RNA was extracted and subjected to miR microarray and bioinformatics analysis. Based on the comprehensive analysis, expression of miRs including its target was analyzed by quantitative reverse transcription-polymerase chain reaction (qRT-PCR), western blot analysis and immunohistochemistry (IHC). Further functional analyses were conducted including proliferation, invasion and apoptosis. miR-205 was identified as downregulated (less than 0.5 -fold) in BLBC relatively to normal
\end{abstract}

Correspondence to: Dr Bing Guan, Department of Pathology, Shanghai 6th People's Hospital Jinshan Branch, Shanghai 201599, P.R. China

E-mail: g_bguan@sina.com

*Contributed equally

Abbreviations: BLBC, basal-like breast carcinoma; miR, microRNA; qRT-PCR, quantitative reverse transcription-polymerase chain reaction; IHC, immunohistochemistry; $\mathrm{NC}$, normal control; GO, gene ontology; KLF12, Krüppel-like factor 12; UTR, untranslated region; AP-2, activating protein-2; Her-2, human epidermalgrowth factor receptor-2; ZEB, zinc finger E-box binding homeobox; CtBP1, C-terminal-binding protein 1; H\&E, hematoxylin and eosin; FBS, fetal bovine serum; FISH, fluorescence in situ hybridization; ER, estrogen receptor; PR, progesterone receptor; CK, cytokeratin; EGFR, epidermal growth factor receptor; FDR, false discovery rate; GAPDH, glyceraldehyde 3-phosphate dehydrogenase; CCK-8, cell counting kit-8 assay; FITC, fluorescein isothiocyanate

Key words: microRNA-205, Krüppel-like factor 12, basal-like breast carcinoma, microarray, bioinformation, tumor suppressor gene, proto-oncogene, invasion, apoptosis, biomarker, microRNA-205, KLF12, AP- $2 \alpha$ axis control (NC). Gene ontology (GO) analysis suggested miR-205 may directly targeted Krüppel-like factor 12 (KLF12; degree $=4)$. Luciferase assay revealed miR-205 directly targeted KLF12 through binding its 3'-untranslated region (3'-UTR; p=0.0016). qRT-PCR and western blot analysis showed miR-205 expression was low in cells $(\mathrm{p}=0.007)$ and tumor tissues ( $\mathrm{n}=6 ; \mathrm{p}=0.0074)$, and KLF12 RNA/protein was observed at high levels in cells $(p=0.0026 ; p=0.0079)$ and tumor tissues ( $\mathrm{n}=9 ; \mathrm{p}=0.0083)$; knock-up of miR-205 increased its expression $(\mathrm{p}=0.0021)$ but reduced KLF12 RNA/protein levels ( $\mathrm{p}=0.0038 ; \mathrm{p}=0.009)$ in cells. Modulation of miR-205 expression by transfecting its mimics in cells, was involved in invasion $(\mathrm{p}=0.00175)$ and apoptosis $(\mathrm{p}=0.006)$. In conclusion, our results supported that miR-205 was a miR specific to BLBC which functioned as tumor suppressor gene through directly targeting and negatively regulating proto-oncogene KLF12. miR-205 dysregulation was involved in invasion and apoptosis. miR-205 and KLF12 provided a potential diagnosis biomarker and therapeutic approach for BLBC.

\section{Introduction}

Breast cancer is the most frequently diagnosed cancer and the leading cause of cancer death worldwide (1). It alone accounts for $25 \%$ of all cancer cases and $15 \%$ of all cancer deaths among females (1). However, breast cancer presents as a heterogeneous disease, not only from clinical and histological perspectives but also from the view of genetic expression (2). Gene microarray profiling have led to the re-categorization of invasive breast carcinomas into 5 distinct subtypes; luminal A, luminal B, normal breast like, human epithelial growth factor receptor-2 (Her-2) overexpressing, and basal-like $(2,3)$. Basal-like and Her-2 groups, however, have more aggressive clinical behavior than the others (4). The basal-like subtype is the least prevalent and the most aggressive one, but it lacks a target based therapy since its triple-negative characteristic (5). miRs are small, non-coding RNAs that negatively regulate gene expression by their interaction with 3'-untranslated region (3'-UTR) of specific target miRs (6), each of which is 
capable of regulating hundreds of protein-coding genes (7). miRs are involved in biological and pathologic processes, including cell differentiation, proliferation, apoptosis and metabolism (8). Accumulating evidence indicates that the dysregulation of miRs has been identified in human cancer, but only a few of these miRs have been functionally documented in breast cancer $(6,9)$. Some previous studies showed distinct differences in miR expression patterns and function between breast cancer cells and NC (10-12).

miR-205 dysregulationg was identified with a series of tumors in recent studies (13). miR-205 was downregulated and functioned as a tumor suppressor gene in breast cancer (14) and prostate cancer (15), miR-205 was an esophageal squamous cell carcinoma-specific miR that exerts tumor-suppressive activities with epithelial mesenchymal transition inhibition by targeting zinc finger E-box binding homeobox (ZEB)2 (16), miR-205 was a glioma-specific tumor suppressor by targeting vascular endothelial growth factor-A(17), miR-205 was a candidate tumor suppressor that targets ZEB2 in renal clear cell carcinoma (18). miR-205 acts either as a tumor suppressor through inhibiting proliferation and invasion, or as an oncogene through facilitating tumor initiation and proliferation, depending on the specific tumor context and target genes (19). Krüppel-like factor (KLF) and share a three-C2H2 zinc finger DNA binding domain which are involved in cell proliferation and differentiation in both normal and pathological situations (20). KLF family members play an important role in the growth and metastasis and cell cycle of different tumor types (20). KLF12, members of KLF family, binds to the CAGTGGG sequence within target gene promoter regions and represses target gene expression through an N-terminal Pro-Xaa-AspLeu-Ser sequence that promotes a physical interaction with the co-repressor C-terminal binding protein 1 (CtBP1) (21). Several studies revealed the differentially expressed KLF12 in human tissues. Nakamura et al introduced KLF12 cDNA into NIH3T3 and AZ-521 cell lines and found that overexpression significantly enhanced their invasive potential (22). Shen et al reported that KLF12, suppressed by 8-Br-cyclic adenosine monophosphate and medroxyprogesterone acetate, negatively regulated human endometrial stromal cells decidualization by inhibiting decidual prolactin and insulin-like growth factor binding protein-1 expression (23).

miR-205 dysregulation was identified with a series of tumour. However, there was little information on the functional roles of miRs specific and its target gene for basal-like breast carcinoma (BLBC). In our previously miRs microarray assay, differentially expression miRs were identified in BLBC. Further bioinformatic analysis revealed KLF12 may be directly targeted by miR-205. Therefore, the study was designed to identify specifically expression miRs and its target gene and distinct biological actions in BLBC.

\section{Materials and methods}

Breast tumor samples. Human breast cancer tissues and paired non-cancerous tissues were collected at Shanghai 6th People's Hospital Jinshan Branch. The samples were immediately snap-frozen in liquid nitrogen and stored at $-80^{\circ} \mathrm{C}$ for DNA/RNA extraction. Hematoxylin and eosin (H\&E) sections were reviewed by two pathologists. Assessment of histological grade were using Bloom (25) and Richardson methods modified by Elston and Ellis (24). The study was approved by Shanghai 6th People's Hospital Jinshan Branch Medical Ethics Committee and an informed consent was obtained for the use of tissue samples from each patient.

Cell lines and culture. The human mammary epithelial cell lines MCF-10A and the basal-like breast cancer cell lines MDA-MB-468 (basal-like) (26) were obtained from the Chinese Academy of Sciences Cell Bank (Shanghai, China). MCF-10A cells were maintained in DMEM/F12 (1:1) supplemented with $5 \%$ horse serum (both from Invitrogen), EGF (20 ng/ml; Peprotech), hydrocortisone $(0.5 \mu \mathrm{g} / \mathrm{ml})$, cholera toxin $(100 \mathrm{ng} / \mathrm{ml})$, insulin $(10 \mu \mathrm{g} / \mathrm{ml})$ (all from Sigma) cultured in $5 \% \mathrm{CO}_{2}$ at $37^{\circ} \mathrm{C}$. MDA-MB-468 cells were maintained in L-15 supplemented with $10 \%$ fetal bovine serum (FBS), cultured in $100 \%$ air at $37^{\circ} \mathrm{C}$.

Transfection. Cells were plated in 12-well plates and transfected at $80-90 \%$ confluence with GenePharma (Shanghai, China) miR mimics (miR-205 mimics, miR-205 mimics NC) and inhibitors (miR-205 inhibitor, miR-205 inhibitor $\mathrm{NC}$ ) at a final concentration of $100 \mathrm{nM}$ in OPTI-MEM using Lipofectamine 2000 (Invitrogen) according to manufacturer's instruction. L-15 containing 10\% FBS was added $6 \mathrm{~h}$ after transfection. The transfected cells were used for functional studies or harvested for RNA and protein analyses as described after 48 h culture.

Immunohistochemistry (IHC) and fluorescence in situ hybridization (FISH). Breast tissue samples were fixed in $4 \%$ formalin/ phosphate-buffered saline. Tissues were dehydrated, embedded in paraffin and cut. Consecutive $4 \mu \mathrm{m}$ thick sections were analyzed by IHC using a panel of antibodies against estrogen receptor (ER; 1:100), progesterone receptor (PR; 1:100) (both from Neomarkers), cytokeratin (CK) 5/6 (1:100; Dako), CK14 (Dako), p63 (1:500; Neomarkers), epidermal growth factor receptor (EGFR; 1:50), p53 (1:100), and Ki-67 (1:75) (all from Dako) in order to identify BLBC molecular subtypes $(2,3,27)$. KLF12 (1:100; Santa Cruz Biotechnology, Inc., Santa Cruz, CA, USA) expression pattern was also analyzed using IHC. IHC staining was performed according to manufacturer's instructions. 3,3N-Diaminobenzidine Tertrahydrochloride (Dako) systems were used for detection. Her-2 was stained with a HercepTest kit (Dako). For each stain, the percentage of positive cells was recorded. Marker expression over $10 \%$ within tumor cells was considered positive. Marker expression under $10 \%$ within tumor cells was considered negative. For Her-2, only cases with a membranous staining score of 3 were considered positive.

FISH was performed for the detection of Her-2 amplification. The probe mix consisted of a mixture of Texas-Red-labeled DNA probes covering a $218-\mathrm{kb}$ region including the Her-2 gene on chromosome-17 (CEN-17) and a mixture of fluorescencelabeled DNA probes targeted at the centromere region of CEN-17. Section preparation and hybridization were performed according to manufacturer's instructions (Dako). Wherever possible, we calculated 30 nuclei per tissue specimen. Specimens with Her-2/CEN-17 ratios over 2.2 were considered 
to have undergone Her-2. For specimens with borderline ratios (1.8-2.2), an additional 30 nuclei were counted and the ratio was recalculated with 60 nuclei. Specimens with Her-2/CEN-17 ratios under 1.8 were considered to be free of Her-2 amplification.

RNA extraction. Total RNA was isolated including tissue samples and cultured cells using TRIzol reagent (Invitrogen) and then treated with RNase-free DNaseI (Promega). Quality of total RNA was determined on an RNA Nano kit (Bioanalyzer), and the RNA was quantified using a spectrophotometer (Nanodrop-1000; NanoDrop). Extracted RNA samples were stored at $-80^{\circ} \mathrm{C}$ until used.

LNA-based miR microarray and bioinformatics analysis. To identify miRs specific for BLBC, total RNA was extracted from BLBC tissues and paired non-cancerous tissues. The isolated RNA samples were subjected to comprehensive analysis of miRs expression patterns with the microarray-based technology. Purified RNA was labeled with a miRCURY Hy3/Hy5 labeling kit (Exiqon). The Hy3 ${ }^{\mathrm{TM}}$-labeled samples and $\mathrm{Hy} 5^{\mathrm{TM}}$-labeled reference pool RNA samples were then mixed pair-wise and hybridized to the miRCURY LNA array version 11.0 (Exiqon). The hybridization was performed according to the manufacturer's instructions. To identify miRs that were differentially expressed between the BLBC tissues and $\mathrm{NC}$, supervised analysis was performed using hierarchical clustering analysis (Cluster 3.0).

GO analysis was used to organize genes into hierarchical categories and revealed the miR-gene regulatory network on the basis of biological process and molecular functions (28-30). In detail, the one-sided Fisher's exact test and $\chi^{2}$-test were used to establish GO categories, and the false discovery rate (FDR) was calculated to correct the p-values (31-33). Only GOs that had p-values $<0.01$ and FDRs $<0.05$ were chosen. Three datasets of miRs and their predicted targets were also used in this study: TargetScan, PicTar and miRanda (34-37). SigTerms software was used to perform GOs analysis simultaneously (38). SigTerms were developed as a set of Excel macros through Excel Visual Basic for Applications using both the selected gene set and the entire set of gene-to-miR associations (38). Affymetrix probe identifiers were mapped to Entrez gene identifiers using version 21 of the U133A annotation. The network of miR-mRNA interactions, representing the critical miRs and their targets, was established according to the miRs degree (38). For interactive viewing of the network, Pajek software was used to process networks of miR-mRNA interaction (39).

$q R T$-PCR.Expression levels of miRs and KLF12 which showed significant differences based on the microarray and bioinformatic results were analyzed by qRT-PCR using cell lines and tissue samples. cDNA was prepared from total RNA using an All-in-One miRNA qRT-PCR detection kit (GeneCopoeia) following the protocol provided by the manufacturer. All PCR reactions were performed in $20 \mu \mathrm{l}$ aliquots containing $2 \mu \mathrm{l}$ first-strand cDNA with $18 \mu 1$ PCR master mixture (10 $\mu 1 \mathrm{qPCR}$ mix, $2 \mu \mathrm{l}$ qPCR primer, $2 \mu \mathrm{l}$ universal Adaptor PCR Primer and $2 \mu \mathrm{l}$ RNase-free water), and run in triplicate on the iQ5 real-time PCR detection system (Bio-Rad). Thermal cycling was initiated with a first denaturation step at $95^{\circ} \mathrm{C}$ for $10 \mathrm{~min}$, followed by 40 cycles of $95^{\circ} \mathrm{C}$ for $10 \mathrm{sec}$ and $60^{\circ} \mathrm{C}$ for $20 \mathrm{sec}$ and $72^{\circ} \mathrm{C}$ for $30 \mathrm{sec}$. The cycle passing threshold $(\mathrm{Ct})$ was recorded. After normalization to glyceraldehyde 3-phosphate dehydrogenase (GAPDH) mRNA, relative expression levels and fold induction of each target gene were calculated using the comparative $\mathrm{CT}(\Delta \Delta \mathrm{CT})$ methods (40).

Western blot analysis. Total protein was extracted using the Total Protein Extraction kit (Thermo Pierce). Tissues and cells were lysed in RIPA buffer supplemented with protease inhibitors according to the manufacturer's instructions. Lysates were separated on a $10 \%$ acrylamide gel and subjected to western blot analysis. Immunoblots were incubated overnight at $4^{\circ} \mathrm{C}$ with the following primary antibodies: anti-KLF12 (1:200) and anti- $\beta$-actin $(1: 2,000)$ (both from Santa Cruz Biotechnology, Inc.) were used as loading controls. Peroxidase-labeled secondary antibodies (1:2,000; Santa Cruz Biotechnology, Inc.) were used to visualize bands using the enhanced chemiluminescence kit (Amersham) on gel image analysis system (Tanon).

Cell proliferation assay. Cell proliferation was determined by the cell counting kit-8 assay (CCK-8; Obio Technology, Shanghai, China). After transfection and culture for $48 \mathrm{~h}$, MDA-MB-468 cells were plated at a density of $2 \times 10^{4}$ cells $/ \mathrm{ml}$ on 96-well plates and cultured in $100 \% \mathrm{CO}_{2}$ at $37^{\circ} \mathrm{C}$. In each detection point, $10 \mu \mathrm{l}$ CCK-8 solution reagent was added to each well. Four hours later, the plates were read in a microplate autoreader (infinite M1000; Tecan) at wavelength of $450 \mathrm{~nm}$. The results were expressed as the mean optical density for selected paradigms performed in triplicate.

Transwell invasion assay. Matrigel invasion assay was performed using a 24-well invasion chamber system (BD Biosciences) with polycarbonic membrane (diameter: $6.5 \mathrm{~mm}$, pore size $8 \mu \mathrm{m}$ ). Cells were plated on the top of Matrigel-coated invasion chambers in a serum-free L-15. As a chemo-attractant, L-15 containing 10\% of FBS was added to the lower compartment of the chamber. The cells were incubated for $24 \mathrm{~h}$. Invasion of cells to the underside of the Matrigel-coated membrane was detected by staining the cells with Mayer's hematoxylin solution and visualizing the cells under a microscope. After staining, cells were counted under a microscope in four random fields (magnification, x100) and results were expressed in the form of a bar graph. Assays were done in triplicate for each experiment, and each experiment was repeated three times.

Quantitation of apoptosis. The Annexin V-fluorescein isothiocyanate (FITC) apoptosis detection kit (Beyotime) was used to detect and quantify apoptosis by flow cytometry. In brief, L-15 containing 10\% FBS was added $6 \mathrm{~h}$ after transfection. Then, cells were cultured $72 \mathrm{~h}$ and collected by centrifugation for $5 \mathrm{~m}$ at 2,000 rpm. Cells were resuspended at a density of $1-5 \times 10^{6}$ cells $/ \mathrm{ml}$ by added $500 \mu \mathrm{l}$ binding buffer, then $5 \mu \mathrm{l}$ Annexin V-EGFP and $5 \mu \mathrm{l}$ propidium iodide were added for 5-10 min, and analyzed by FACSVerse ${ }^{\mathrm{TM}}$ Flow Cytometer (Becton-Dickinson) in $1 \mathrm{~h}$. The data obtained were analyzed using CellQuest software. 
KLF12 3'-UTR construction and luciferase reporter assay. For the luciferase reporter assays, KLF12 3'-UTR, including the $X h o I$ and Not I restriction sites, was synthesised and then cloned into the psiCHECK-2 Vector (Promega) using the XhoI and NotI (both from NEB) restriction sites. HEK-293T cells were seeded into 48 -well plate at a density of 70-80\% cells/well. After overnight incubation, the cells were treated with transfection mixture consisting of $25 \mu \mathrm{l}$ of serum-free medium diluting $100 \mathrm{ng}$ psiCHECK-KLF12 (V1), $25 \mu \mathrm{l}$ of serum-free medium diluting mir-205 (V2) and $25 \mu \mathrm{l}$ of serum-free medium diluting Lipofectamine 2000 (V3; Invitrogen). Forty-eight hours post-transfection Renilla and Firefly luciferase activities were measured using the Dual-Luciferase Reporter assay system (Promega). Firefly activity was normalized to Renilla activity to control the transfection efficiency.

Statistical analysis. All data were expressed as mean \pm SD. The differences between groups were analyzed using the Student's t-test. Statistical difference at p-values $<0.05$ and significantly statistical difference at $\mathrm{p}$-values $<0.01$. The statistical software SPSS 16.0 (IBM, Armonk, NY, USA) was used for analysis of Student's t-test.

\section{Results}

$B L B C$ identification, miR microarray and $G O$ analysis. Eighteen cases were identified as BLBC (ER, PR and Her-2 negative; CK5/6, CK14, p63, EGFR and p53 positive; Ki-67 high proliferation index; Her-2 no-amplification) (Fig. 1A).

Using the miR microarray, it first evaluated the miR expression profiles in BLBC $(n=3)$ and $\mathrm{NC}(\mathrm{n}=3)$. The expression profiles of $265 \mathrm{miRs}$ were determined to differ between BLBC and NC which were sufficient to separate samples into biologically interpretable groups. Thus, $11 \mathrm{miRs}$ were identified as upregulated ( $>2$-fold) and $18 \mathrm{miRs}$ were identified as downregulated $(<0.5$-fold) between BLBC and NC (Fig. 1B and Table I).

GOs analysis displayed up/downregulation of miRs which were significantly involved in the positive/negative regulation of nucleobase, nucleoside, nucleotide and nucleic acid metabolic processes (Tables II and III). miRs were found to interact with the genes relating to those processes, suggesting miRs play an important role in the pathogenesis of BLBC. The miR-mRNA regulatory networks based on positive/negative regulation of nucleobase, nucleoside, nucleotide, and nucleic acid metabolic processes were established (Fig. 1C and D and Tables IV and V), and the assumed targeted mRNAs of up/downregulation miRs were identified. Three upregulation miRs (miR-141/106b /200c) displayed the most targeted mRNAs of three (degree 3 ). Two downregulation miRs (miR-205/129-5p) showed the most targeted mRNAs of two (degree 2). All three upregulation miRs (miR-141/106b/200c) targeted KLF12 and only one downregulation miR (miR-205) targeted KLF12. So, KLF12 had the highest degree of four (degree 4) in the up/ downregulation miR-mRNA regulatory network. GO analysis suggested KLF12 may be targeted by miR-205/141/106b/200c and showed potentially the most important genes affecting positive/negative regulation of nucleobase-, nucleoside-, nucleotide- and nucleic-acid-metabolic-related processes.
miR-205 directly targeted KLF12 through binding its 3'-UTR. To determine whether KLF12 was directly targeted by miR-205/141/106b (miR-200c context score percentile was too low and was discard), the wild-type 3'-UTR of KLF12 and mutant were constructed and inserted into the luciferase reporter plasmid. The wild-type or mutant vectors were co-transfected with miR-205/141/106b mimics or negative control miRs in MDA-MB-468 cells. Co-transfection of the reporter plasmid along with miR-205 resulted in significantly reducing KLF12-WT-3'-UTR-luciferase expression than its $\mathrm{NC} \mathrm{miR} \mathrm{+} \mathrm{KLF12-WT}(\mathrm{p}=0.0016)$ or miR-205 + KLF12-Mut (p=0.0011) (Fig. 2A and B) groups; however, no KLF12-Mut-3'UTR-luciferase expression variation was observed compared to its NC miR + KLF12-Mut (Fig. 2A and B). Co-transfection of the reporter plasmid along with miR-141/106b did not result in the reduction of KLF12-WT/Mut-3'-UTR-luciferase expression compared to its $\mathrm{NC} \mathrm{miR}+\mathrm{KLF} 12-\mathrm{WT} / \mathrm{Mut}$ (Fig. 2-F). This supported miR-205 was likely to target KLF12 directly.

miR-205 downregulates in BLBC cells/tissues and negatively modulates KLF12. Based on the microarray and bioinformation and luciferase assay, qRT-PCR and western blot analysis were used to relatively quantify expression levels of miR-205 and KLF-12. miR-205 had low expression in MDA-MB-468 cells, significantly lower than in MCF10A cells $(p=0.007)$ (Fig. 3A); knock-up of miR-205 by transfection with miR-205 mimics in MDA-MB-468 cells, its expression levels substantially increased, and was significantly higher than in mimics of $\mathrm{NC}$ in cell lines $(\mathrm{p}=0.0021)$ (Fig. 3A); knockdown of miR-205 by transfection with miR-205 inhibitor in MDA-MB-468 cells, its expression levels substantially reduced, and was lower than in inhibitor $\mathrm{NC}$ in cell lines ( $\mathrm{p}=0.034)$ (Fig. 3A). In BLBC tumor tissues, miR-205 had significantly lower expression levels than in the $\mathrm{NC}(\mathrm{n}=9 ; \mathrm{p}=0.0074)$ (Fig. 3B). KLF12 had high expression in MDA-MB-468 cells, significantly higher than it in MCF10A cells $(\mathrm{p}=0.0026)$ (Fig. 3C); knock-up of miR-205 by transfection with miR-205 mimics in MDA-MB-468 cells, its expression levels substantially reduced, and was significantly lower than in mimics of NC in cell lines $(p=0.0038)$ (Fig. 3C); knockdown of miR-205 by transfection with miR-205 inhibitor in MDA-MB-468 cells, its expression levels substantially increased, and was higher than in inhibitor $\mathrm{NC}$ in cell lines $(p=0.043)$ (Fig. 3C). KLF12 protein showed high expression levels in MDA-MB-468 cells, significantly higher than in MCF10A cells ( $p=0.0079$ ) (Fig. 3D); knock-up of miR-205 by transfection with miR-205 mimics in MDA-MB-468 cells, its expression level substantially reduced, and was significantly lower than in the mimics of $\mathrm{NC}$ in cell lines $(p=0.009)$ (Fig. 3D); knockdown of miR-205 by transfection with miR-205 inhibitor in MDA-MB-468 cells, its expression levels substantially increased, and was higher than in inhibitor $\mathrm{NC}$ in cell lines $(\mathrm{p}=0.035)$ (Fig. 3D). In BLBC tumor tissues, KLF12 protein was higher expressed than in $\mathrm{NC}(\mathrm{n}=9 ; \mathrm{p}=0.0083)$ (Fig. 3E). IHC results displayed positive rates of KLF12 at $88.9 \%(16 / 18)$ in $\mathrm{BLBC}$ and $0 \%$ in normal breast non-cancerous tissues, and its expression pattern was nuclear positive in the normal ductal inner epithelium and outer myoepithelial cells (Fig. 3F) but diffuse nuclear positive in BLBC tumor cells (Fig. 3G). It indicated downregulation 
A

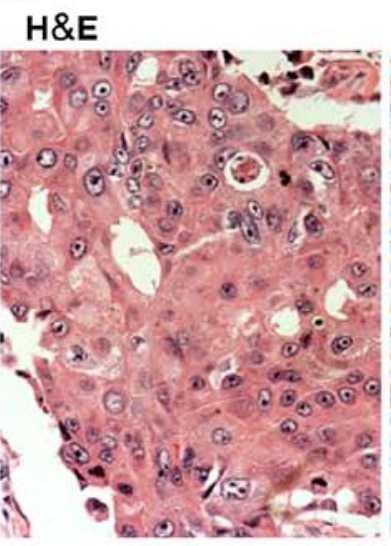

CK $5 / 6$

CK 14
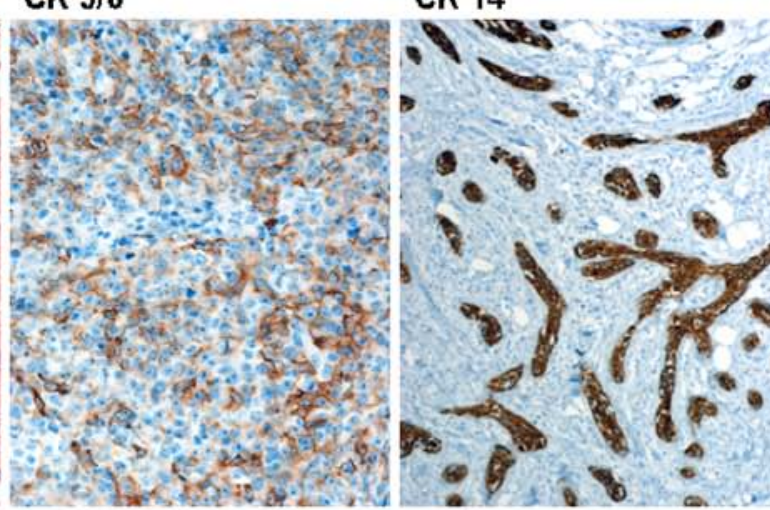

p63

EGFR

p53

Ki 67
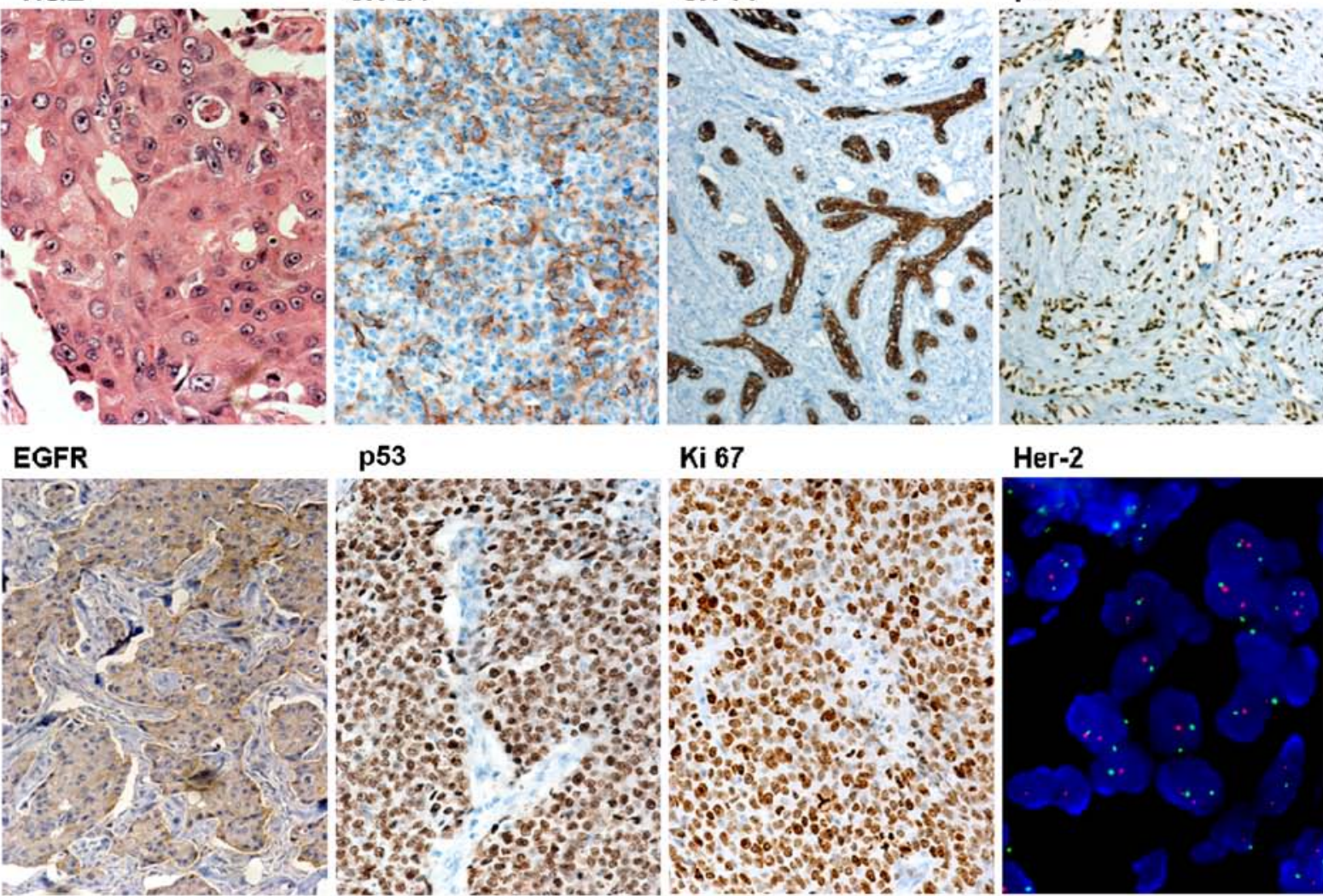

सy

Her-2

B
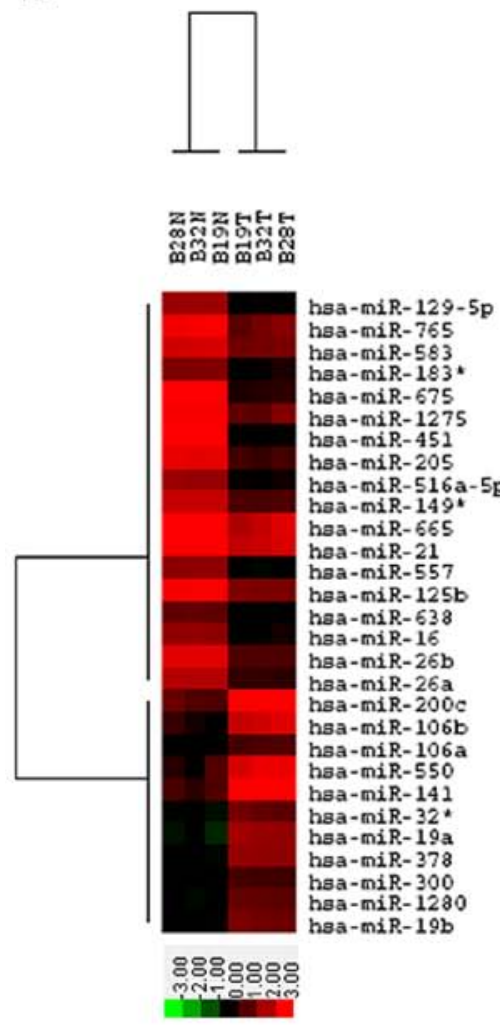

C

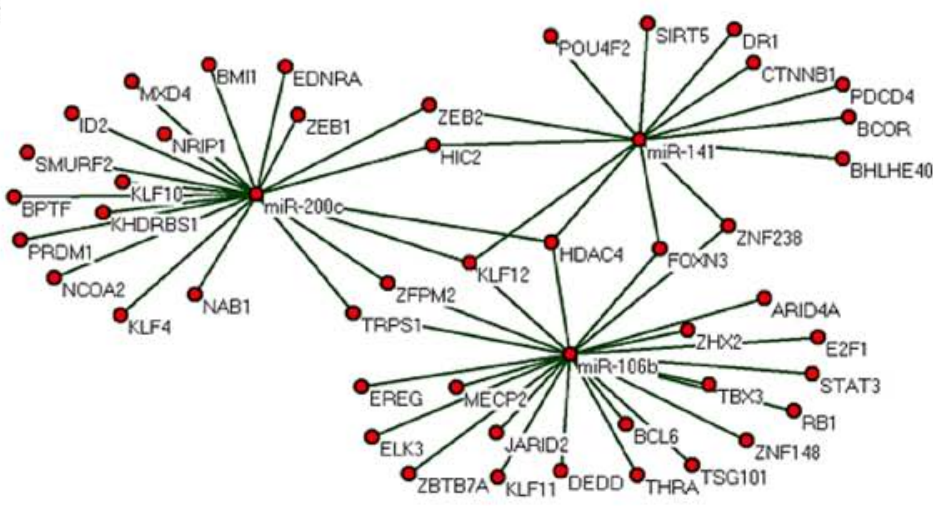

$\mathbf{D}$

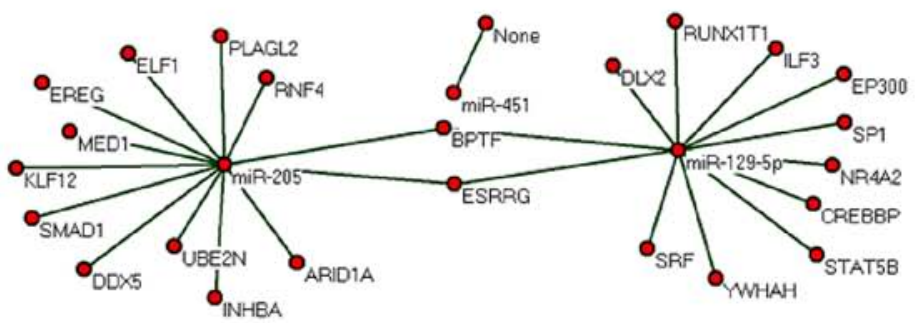

Figure 1. BLBC identification and miR microarray and bioinformatics analysis. (A) Identification of BLBC: HE showed large tumor cells, eosinophilic cytoplasm and obvious nucleoli; IHC showed CK5/6 cytoplasm positive (x400), CK14 cytoplasm positive (x400), p63 nucleus positive (x400), EGFR membrane positive (x400), p53 nucleus positive (x400), Ki-67 high proliferation index (x400); FISH showed no Her-2 amplification (x400). (B) Heat map summarizes the biological replicates for BLBC and its normal control, the highest expression value corresponds to bright red and the lowest to bright green, gene names are listed on the right. (C and D) Network analysis displayed the BLBC up/downregulation miR-mRNA network, KLF12 had the highest degree of 4 in the network, red cycle nodes represente miRNA and mRNA, respectively, edges describe the inhibitive effect of miRNA on mRNA. 
Table I. The miR microarray identified between BLBC and NC.

\begin{tabular}{|c|c|c|c|c|c|c|}
\hline miRNA & $\begin{array}{l}\text { Genomic } \\
\text { location }\end{array}$ & $\begin{array}{l}\text { Normal } \\
\text { control } \\
\text { mean }\end{array}$ & $\begin{array}{l}\text { Basal-like } \\
\text { breast } \\
\text { carcinoma } \\
\text { mean }\end{array}$ & $\begin{array}{l}\text { Fold- } \\
\text { change }\end{array}$ & P-value & Function \\
\hline \multicolumn{7}{|l|}{$\begin{array}{l}\text { Upregulated } \\
\text { microRNAs }\end{array}$} \\
\hline hsa-miR-19a & chr13:92003145-92003226 [+] & 0.621 & 6.427 & 10.349 & 0.001 & \\
\hline hsa-miR-19b & chr13:92003446-92003532 [+] & 1.201 & 4.173 & 3.475 & 0.002 & \\
\hline hsa-miR-32* & chr9:110848330-110848399 (-) & 0.728 & 3.689 & 5.067 & 0.007 & \\
\hline hsa-miR-106a & chrX:133131894-133131974 (-) & 0.886 & 2.812 & 3.174 & 4.99E-05 & \\
\hline hsa-miR-106b & chr7:99529552-99529633 (-) & 1.721 & 12.367 & 7.186 & 0.009 & $\begin{array}{l}\text { Negative regulation of } \\
\text { nucleobase, nucleoside, nucleotide } \\
\text { and nucleic acid metabolic process }\end{array}$ \\
\hline hsa-miR-141 & chr12:6943521-6943615 (+) & 2.690 & 33.968 & 12.628 & 0.006 & $\begin{array}{l}\text { Negative regulation of nucleobase, } \\
\text { nucleoside, nucleotide and nucleic } \\
\text { acid metabolic process }\end{array}$ \\
\hline hsa-miR-200c & chr12:6943123-6943190 (+) & 3.218 & 28.935 & 8.992 & $2.52 \mathrm{E}-06$ & $\begin{array}{l}\text { Negative regulation of nucleobase, } \\
\text { nucleoside, nucleotide and nucleic } \\
\text { acid metabolic process }\end{array}$ \\
\hline hsa-miR-300 & chr14:100577453-100577535 (+) & 0.990 & 2.609 & 2.635 & 0.002 & \\
\hline hsa-miR-378 & chr5:149092581-149092646 (+) & 0.861 & 5.812 & 6.750 & 8.33E-06 & \\
\hline hsa-miR-550 & chr7:30295935-30296031 (+) & 1.993 & 15.519 & 7.787 & 0.004 & \\
\hline hsa-miR-1280 & $\operatorname{chr} 3: 128081008-128081101[+]$ & 0.784 & 3.505 & 4.471 & $3.98 \mathrm{E}-05$ & \\
\hline \multicolumn{7}{|l|}{$\begin{array}{l}\text { Downregulated } \\
\text { microRNAs }\end{array}$} \\
\hline hsa-miR-16 & chr13:49521110-49521198 (-) & 5.741 & 1.436 & 0.250 & $6.92 \mathrm{E}-06$ & \\
\hline hsa-miR-21 & chr17:55273409-55273480 (+) & 44.750 & 11.610 & 0.259 & 4.08E-05 & \\
\hline hsa-miR-26a & chr3:37985899-37985975 (+) & 8.999 & 2.059 & 0.229 & 3.29E-07 & \\
\hline hsa-miR-26b & chr2:218975613-218975689 (+) & 14.630 & 2.872 & 0.196 & $5.05 \mathrm{E}-07$ & \\
\hline hsa-miR-125b & chr11:121475675-121475762 (-) & 19.029 & 4.617 & 0.243 & $1.03 \mathrm{E}-08$ & \\
\hline hsa-miR-129-5p & chr7:127635161-127635232 (+) & 6.690 & 1.356 & 0.203 & 8.08E-07 & $\begin{array}{l}\text { Positive regulation of nucleobase, } \\
\text { nucleoside, nucleotide and nucleic } \\
\text { acid metabolic process }\end{array}$ \\
\hline hsa-miR-149* & chr2:241044091-241044179(+) & 10.663 & 2.809 & 0.263 & $3.92 \mathrm{E}-08$ & \\
\hline hsa-miR-183* & chr7:129201981-129202090 (-) & 4.862 & 1.391 & 0.286 & 0.001 & \\
\hline hsa-miR-205 & chr1:207672101-207672210 (+) & 15.581 & 2.492 & 0.159 & $2.05 \mathrm{E}-07$ & $\begin{array}{l}\text { Positive regulation of nucleobase, } \\
\text { nucleoside, nucleotide and nucleic } \\
\text { acid metabolic process }\end{array}$ \\
\hline hsa-miR-451 & chr17:24212513-24212584 (-) & 20.532 & 1.310 & 0.064 & 0.001 & $\begin{array}{l}\text { Positive regulation of nucleobase, } \\
\text { nucleoside, nucleotide and nucleic } \\
\text { acid metabolic process }\end{array}$ \\
\hline hsa-miR-516a-5p & chr19:58951807-58951896 (+) & 6.400 & 1.439 & 0.225 & 9.62E-06 & \\
\hline hsa-miR-557 & chr1:166611386-166611483 (+) & 5.742 & 0.803 & 0.139 & $2.33 \mathrm{E}-06$ & \\
\hline hsa-miR-583 & chr5:95440598-95440672(+) & 12.464 & 4.260 & 0.342 & $3.52 \mathrm{E}-06$ & \\
\hline hsa-miR-638 & chr19:10690080-10690179 (+) & 3.504 & 0.843 & 0.241 & $1.53 \mathrm{E}-05$ & \\
\hline hsa-miR-665 & chr14:100411123-100411194 (+) & 31.180 & 11.014 & 0.353 & 0.001 & \\
\hline hsa-miR-675 & chr11:1974565-1974637 (-) & 21.107 & 1.905 & 0.09 & 0.001 & \\
\hline hsa-miR-765 & chr1:155172547-155172660 (-) & 18.603 & 4.282 & 0.230 & $6.04 \mathrm{E}-05$ & \\
\hline hsa-miR-1275 & chr6:33967749-33967828 [-] & 18.712 & 3.899 & 0.208 & 0.001 & \\
\hline
\end{tabular}


Table II. GO analysis significant terms based on upregulated miRs.

\begin{tabular}{|c|c|c|c|c|}
\hline Category & Term & $\begin{array}{c}\text { Count in } \\
\text { selected } \\
\text { genes }\end{array}$ & $\begin{array}{c}\text { Count } \\
\text { in total } \\
\text { population }\end{array}$ & P-value \\
\hline GO & Regulation of transcription from RNA polymerase II promoter & 82 & 379 & $1.49 \mathrm{E}-07$ \\
\hline GO & Positive regulation of transcription from RNA polymerase II promoter & 34 & 121 & $2.15 \mathrm{E}-06$ \\
\hline GO & Transcription factor activity & 127 & 715 & 7.79E-06 \\
\hline GO & Positive regulation of transcription, DNA-dependent & 45 & 196 & 2.07E-05 \\
\hline GO & Positive regulation of RNA metabolic process & 45 & 197 & 2.37E-05 \\
\hline GO & Regulation of gene expression & 257 & 1668 & 2.73E-05 \\
\hline GO & Transcription regulator activity & 164 & 1003 & 4.85E-05 \\
\hline GO & Regulation of transcription & 240 & 1579 & 0.000133 \\
\hline $\mathrm{GO}$ & Positive regulation of transcription & 48 & 234 & 0.000221 \\
\hline GO & Regulation of macromolecule biosynthetic process & 253 & 1689 & 0.000222 \\
\hline $\mathrm{GO}$ & $\begin{array}{l}\text { Regulation of nucleobase, nucleoside, nucleotide } \\
\text { and nucleic acid metabolic process }\end{array}$ & 245 & 1630 & 0.00023 \\
\hline GO & Regulation of cellular biosynthetic process & 255 & 1705 & 0.000231 \\
\hline GO & Regulation of biosynthetic process & 255 & 1706 & 0.00024 \\
\hline GO & Positive regulation of gene expression & 48 & 235 & 0.000245 \\
\hline GO & Regulation of RNA metabolic process & 228 & 1509 & 0.000289 \\
\hline GO & $\begin{array}{l}\text { Positive regulation of nucleobase, nucleoside, nucleotide } \\
\text { and nucleic acid metabolic process }\end{array}$ & 49 & 243 & 0.000292 \\
\hline GO & Regulation of transcription, DNA-dependent & 225 & 1495 & 0.000402 \\
\hline GO & Regulation of macromolecule metabolic process & 267 & 1831 & 0.000827 \\
\hline GO & Regulation of cellular metabolic process & 267 & 1834 & 0.000914 \\
\hline GO & Positive regulation of progression through cell cycle & 4 & 5 & 0.001029 \\
\hline GO & Transcriptional repressor activity & 19 & 73 & 0.001033 \\
\hline GO & Rhythmic process & 14 & 47 & 0.001134 \\
\hline GO & Negative regulation of transcription, DNA-dependent & 35 & 169 & 0.00125 \\
\hline GO & Positive regulation of macromolecule biosynthetic process & 50 & 266 & 0.001342 \\
\hline GO & Regulation of metabolic process & 270 & 1869 & 0.001361 \\
\hline GO & Negative regulation of RNA metabolic process & 35 & 170 & 0.001392 \\
\hline GO & Actin cytoskeleton & 21 & 87 & 0.00164 \\
\hline GO & Negative regulation of transcription & 45 & 236 & 0.001697 \\
\hline GO & Suckling behavior & 3 & 3 & 0.001859 \\
\hline GO & Negative regulation of gene expression & 45 & 238 & 0.002019 \\
\hline GO & Positive regulation of cellular biosynthetic process & 50 & 273 & 0.00237 \\
\hline GO & Positive regulation of biosynthetic process & 50 & 275 & 0.002768 \\
\hline GO & Histone acetyltransferase binding & 4 & 6 & 0.002786 \\
\hline GO & Protein serine/threonine kinase activity & 59 & 339 & 0.003442 \\
\hline GO & Phosphate metabolic process & 103 & 651 & 0.003751 \\
\hline GO & Phosphorus metabolic process & 103 & 651 & 0.003751 \\
\hline GO & Phosphoprotein phosphatase activity & 25 & 117 & 0.003804 \\
\hline GO & Protein amino acid dephosphorylation & 23 & 105 & 0.003889 \\
\hline GO & Centrosome & 13 & 48 & 0.004262 \\
\hline GO & Protein serine/threonine phosphatase complex & 9 & 28 & 0.004889 \\
\hline $\mathrm{GO}$ & $\begin{array}{l}\text { Negative regulation of nucleobase, nucleoside, nucleotide } \\
\text { and nucleic acid metabolic process }\end{array}$ & 46 & 257 & 0.0054 \\
\hline GO & Post-translational protein modification & 123 & 806 & 0.005639 \\
\hline GO & Protein kinase cascade & 26 & 128 & 0.006487 \\
\hline GO & Synapse organization and biogenesis & 3 & 4 & 0.006751 \\
\hline GO & Skeletal muscle development & 3 & 4 & 0.006751 \\
\hline $\mathrm{GO}$ & Vascular endothelial growth factor receptor activity & 5 & 11 & 0.006817 \\
\hline GO & Golgi stack & 5 & 11 & 0.006817 \\
\hline GO & MAP kinase kinase kinase activity & 5 & 11 & 0.006817 \\
\hline
\end{tabular}


Table II. Continued.

\begin{tabular}{|c|c|c|c|c|}
\hline Category & Term & $\begin{array}{c}\text { Count in } \\
\text { selected } \\
\text { genes }\end{array}$ & $\begin{array}{c}\text { Count } \\
\text { in total } \\
\text { population }\end{array}$ & P-value \\
\hline GO & Negative regulation of cellular biosynthetic process & 48 & 275 & 0.00739 \\
\hline GO & Negative regulation of transcription from RNA polymerase II promoter & 24 & 117 & 0.007676 \\
\hline GO & System development & 60 & 359 & 0.007845 \\
\hline GO & Negative regulation of biosynthetic process & 48 & 276 & 0.00791 \\
\hline GO & Protein serine/threonine phosphatase activity & 8 & 25 & 0.008086 \\
\hline $\mathrm{GO}$ & Protein kinase activity & 73 & 452 & 0.008364 \\
\hline GO & Actin cytoskeleton organization and biogenesis & 17 & 75 & 0.008522 \\
\hline GO & Dephosphorylation & 24 & 118 & 0.008544 \\
\hline GO & Small conjugating protein ligase activity & 23 & 112 & 0.008812 \\
\hline GO & Positive regulation of myeloid cell differentiation & 6 & 16 & 0.009191 \\
\hline GO & Regulation of myeloid cell differentiation & 10 & 36 & 0.009608 \\
\hline
\end{tabular}

Table III. GO analysis significant terms based on downregulated miRs.

\begin{tabular}{|c|c|c|c|c|}
\hline Category & Term & $\begin{array}{c}\text { Count in } \\
\text { selected genes }\end{array}$ & $\begin{array}{c}\text { Count in total } \\
\text { population }\end{array}$ & P-value \\
\hline GO & $\begin{array}{l}\text { Positive regulation of nucleobase, nucleoside, nucleotide } \\
\text { and nucleic acid metabolic process }\end{array}$ & 23 & 243 & 0.000412 \\
\hline GO & Positive regulation of myeloid cell differentiation & 5 & 16 & 0.000459 \\
\hline GO & Transcription factor activity & 49 & 715 & 0.001111 \\
\hline GO & Transcriptional repressor activity & 10 & 73 & 0.001221 \\
\hline GO & Regulation of translation & 9 & 61 & 0.001244 \\
\hline GO & Positive regulation of transcription & 21 & 234 & 0.001431 \\
\hline GO & Positive regulation of gene expression & 21 & 235 & 0.001509 \\
\hline GO & UBC13-MMS2 complex & 2 & 2 & 0.00191 \\
\hline GO & mRNA binding & 6 & 32 & 0.002334 \\
\hline GO & Positive regulation of transcription, DNA-dependent & 18 & 196 & 0.002374 \\
\hline GO & Transcriptional activator activity & 11 & 93 & 0.002388 \\
\hline GO & Positive regulation of RNA metabolic process & 18 & 197 & 0.00251 \\
\hline GO & Positive regulation of macromolecule biosynthetic process & 22 & 266 & 0.003118 \\
\hline GO & Post-transcriptional regulation of gene expression & 10 & 83 & 0.003241 \\
\hline GO & Chromatin modification & 14 & 141 & 0.003473 \\
\hline GO & Positive regulation of cellular biosynthetic process & 22 & 273 & 0.004261 \\
\hline GO & Regulation of myeloid cell differentiation & 6 & 36 & 0.004328 \\
\hline GO & Positive regulation of biosynthetic process & 22 & 275 & 0.004646 \\
\hline GO & Natural killer cell differentiation & 2 & 3 & 0.005564 \\
\hline GO & Ubiquitin conjugating enzyme complex & 2 & 3 & 0.005564 \\
\hline GO & Positive regulation of macromolecule metabolic process & 23 & 305 & 0.007789 \\
\hline GO & Positive regulation of cellular metabolic process & 23 & 310 & 0.009385 \\
\hline GO & Regulation of gene expression & 92 & 1,668 & 0.009564 \\
\hline
\end{tabular}

of miR-205 was specific to BLBC, and negatively regulated KLF12 expression by directly targeted its 3'-UTR.

miR-205isnot involved in cellularproliferation.Knock-up/down of miR-205 by transfection with miR-205 mimics/inhibitor with sufficient concentrations to increase/decrease miR-205 expression levels, respectively, had no significant impact on the optical densities of CCK-8 assays (Fig. 4A).

miR-205 involved in cellular invasion and apoptosis. The Transwell Matrigel invasion assay was performed to evaluate the impact of miR-205 on invasive ability of MDA-MB-468 
A KLF12WT 3'-UTR 5'...UGUAUAAUUAUCUGAAUGAAGGC...3'

hsa-miR-205 3'...GUCUGAGGCCUUACUUCCU...5'

KLF12 mut 3'-UTR 5'...UGUAUAAUUAUCUGAAGAGUCGC...3'

MiR-205 target sequence of KLF12 WT:5'...ATGAAGGCATGAAGG...3' A ACTGTATGCATTTGTATAATTATCTGAITGA AGGCATG AAGGTTAAATAAAGCATTTTGT

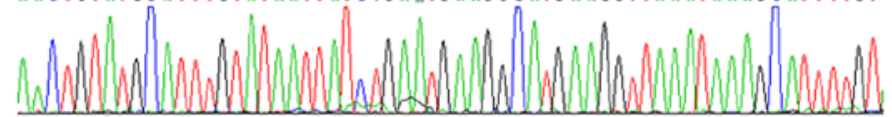

MiR-205 target sequence of KLF12 mut: 5'...AGAGTCGCAGAGTCG...3'

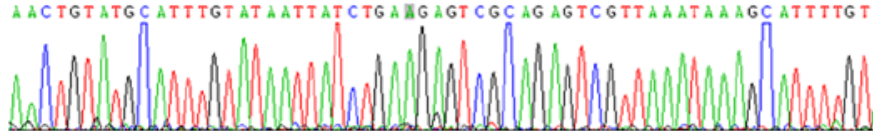

C

KLF12 WT 3'-UTR 5'...GCUGAAUCCCCUUCACAGUGUUA....3'

hsa-miR-141 3'...GGUAGAAAUGGUCUGUCACAAU...5'

KLF12 mut 3'-UTR 5'...GCUGAAUCCCCUUCACUUACGUA...3'

miR -141 target sequence of KLF12 WT: 5'...CAGTGTT...3'

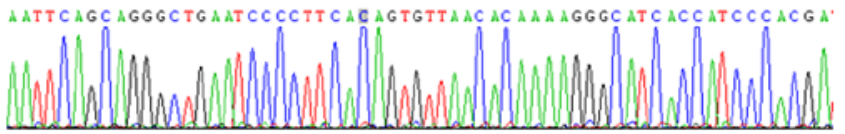

miR-141 target sequence of KLF12 mut: 5'...CTTACGT...3'

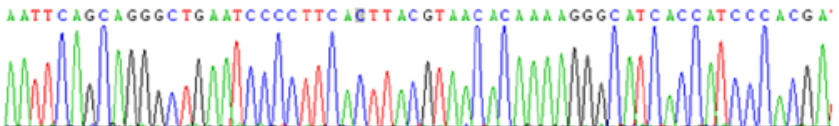

E

KLF12 WT 3'-UTR 5'...UUUUUAAAAAAAUGAGCACUUUU....3'

hsa-miR-106b 3 '...UAGACGUGACAGUCGUGAAAU...5'

KLF12 mut 3'-UTR 5'...UUUUUAAAAAAAUGAGAUGACUU....3'

miR-106b target sequence of KLF12 WT: 5'...GCACTTT ...3'

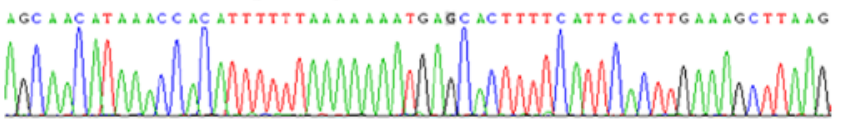

miR-106b target sequence of KLF12 mut: 5'...GATGACT...3'

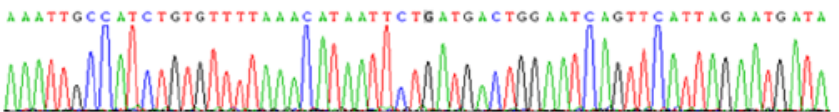

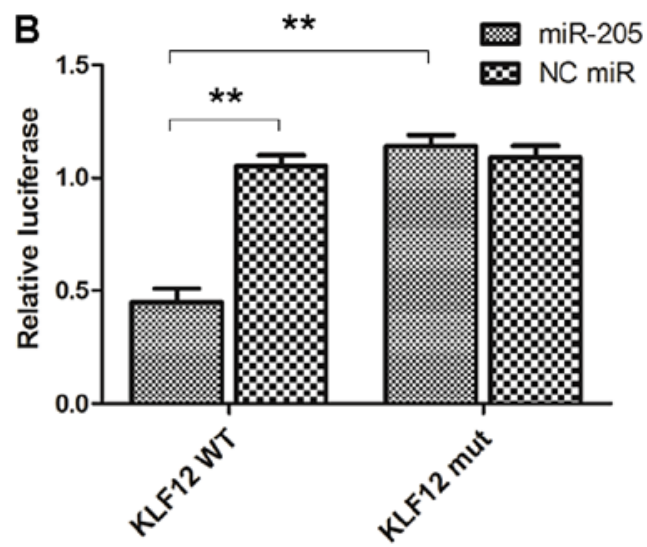

D $m$ miR-141

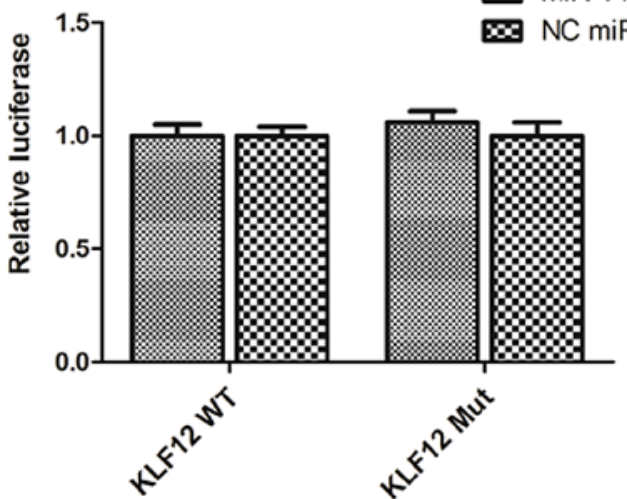

$\begin{array}{ll}1.5 & \text { miR-106b }\end{array}$

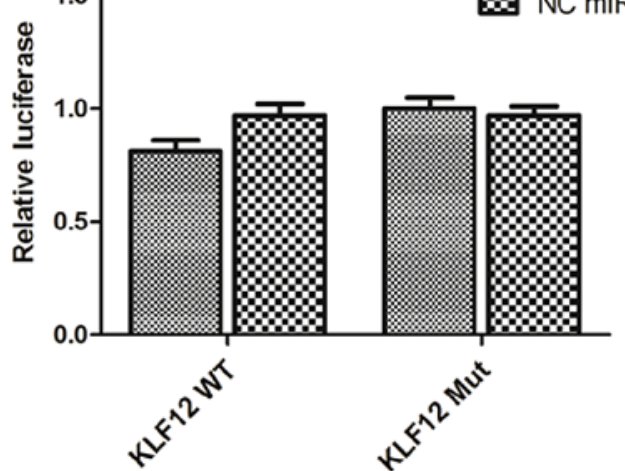

Figure 2. miR-205 directly targeted KLF12. PsiCHECK2-WT KLF12-3'-UTR-Luc and psiCHECK2-mut KLF12-3'-UTR-Luc reporters were transfected into 293T cells which co-transfected with miR-205/141/106b mimics or NC miRs. Luciferase activity was determined $48 \mathrm{~h}$ after transfection. The activity of Firefly luciferase was normalized to that of the control Renilla luciferase in each experiment. The luciferase activity in cell transfection with NC miRs was defined as $100 \%$. (A) Sequences of miR-205 binding sites with KLF12 3'-UTR and mutated nucleotides and gene-sequencing results. (B) Luciferase activity was significantly decreased in miR-205 + KLF12 WT compared to miR-205 + KLF12 mut or NC miRNA + KLF12 WT group. (C) Sequences of miR-141 binding sites with KLF12 3'-UTR and mutated nucleotides and gene-sequencing results. (D) Luciferase activity had no significant difference in miR-141 + KLF12 WT compared to miR-141 + KLF12 mut or NC miRNA + KLF12 WT group. (E) Sequences of miR-106b binding sites with KLF12 3'-UTR and mutated nucleotides and gene-sequencing results. (F) Luciferase activity had no significant difference in miR-106b + KLF12 WT comparing with miR-106b + KLF12 mut or NC miRNA + KLF12 WT group; ${ }^{* *} \mathrm{p}<0.01$.

cells. Knock-up of miR-205 by transfection with miR-205 mimics significantly inhibited the transmembrane ability when compared with miR-205 mimics NC $(\mathrm{p}=0.00175)$ (Fig. 4B) in vitro. Knockdown of miR-205 by transfection with miR-205 inhibitor promoted the transmembrane ability when compared with miR-205 inhibitor $\mathrm{NC}(\mathrm{p}=0.033)$ (Fig. 4B) in vitro. It supported dysregulation of miR-205 was involved in BLBC cell invasion.
The flow cytometric analyses of propidium iodide-stained cells were performed to detect BLBC cell apoptosis rates. The apoptosis rates were significantly different between MDA-MB-468 and MCF-10A cells ( $\mathrm{p}=0.0075)$ (Fig. 4C) in vitro. Knock-up of miR-205 by transfection with miR-205 mimics significantly increased apoptosis rates when compared with miR-205 mimics of $\mathrm{NC}(\mathrm{p}=0.006)$ (Fig. $4 \mathrm{C})$ in vitro. Knockdown of miR-205 by transfection with miR-205 
Table IV. Datasets of up-go miRs and its targets for interactive Table IV. Continued. viewing of the network using Pajek desktop software.

\begin{tabular}{|c|c|c|c|}
\hline \multirow{2}{*}{ Vertices ${ }^{*}$} & \multirow{2}{*}{49} & \multicolumn{2}{|c|}{ Edges* } \\
\hline & & 1 & 9 \\
\hline 1 & miR-106b & 1 & 12 \\
\hline 2 & miR-141 & 1 & 14 \\
\hline 3 & $\mathrm{miR}-200 \mathrm{c}$ & 1 & 15 \\
\hline 4 & ZNF238 & 1 & 17 \\
\hline 5 & $\mathrm{NCOA} 2$ & 1 & 20 \\
\hline 6 & MXD4 & 1 & 23 \\
\hline 7 & KHDRBS1 & 1 & 24 \\
\hline 8 & FOXN3 & 1 & 26 \\
\hline 9 & KLF12 & 1 & 29 \\
\hline 10 & CTNNB1 & 1 & 30 \\
\hline 11 & DR1 & 1 & 31 \\
\hline 12 & $\mathrm{E} 2 \mathrm{~F} 1$ & 1 & 35 \\
\hline 13 & EDNRA & 1 & 36 \\
\hline 14 & ELK3 & 1 & 38 \\
\hline 15 & EREG & 1 & 40 \\
\hline 16 & BPTF & 1 & 41 \\
\hline 17 & ZHX2 & 1 & 42 \\
\hline 18 & HIC2 & 1 & 44 \\
\hline 19 & SIRT5 & 1 & 46 \\
\hline 20 & ZFPM2 & 1 & 48 \\
\hline 21 & PDCD4 & 2 & 4 \\
\hline 22 & ID2 & 2 & 8 \\
\hline 23 & JARID2 & 2 & 9 \\
\hline 24 & MECP2 & 2 & 10 \\
\hline 25 & NAB1 & 2 & 11 \\
\hline 26 & ZBTB7A & 2 & 18 \\
\hline 27 & POU4F2 & 2 & 19 \\
\hline 28 & BCOR & 2 & 21 \\
\hline 29 & RB1 & 2 & 27 \\
\hline 30 & ARID4A & 2 & 28 \\
\hline 31 & BCL6 & 2 & 45 \\
\hline 32 & PRDM1 & 2 & 48 \\
\hline 33 & SMURF2 & 2 & 49 \\
\hline 34 & BMI1 & 3 & 5 \\
\hline 35 & STAT3 & 3 & 6 \\
\hline 36 & TBX3 & 3 & 7 \\
\hline 37 & ZEB1 & 3 & 9 \\
\hline 38 & THRA & 3 & 13 \\
\hline 39 & KLF10 & 3 & 16 \\
\hline 40 & TRPS1 & 3 & 18 \\
\hline 41 & TSG101 & 3 & 20 \\
\hline 42 & ZNF148 & 3 & 22 \\
\hline 43 & NRIP1 & 3 & 25 \\
\hline 44 & KLF11 & 3 & 32 \\
\hline 45 & BHLHE40 & 3 & 33 \\
\hline 46 & DEDD & 3 & 34 \\
\hline 47 & KLF4 & 3 & 37 \\
\hline 48 & HDAC4 & 3 & 39 \\
\hline 49 & ZEB2 & 3 & 40 \\
\hline Edges $^{*}$ & & $\begin{array}{l}3 \\
3\end{array}$ & $\begin{array}{l}43 \\
47\end{array}$ \\
\hline 1 & 4 & $\begin{array}{l}3 \\
3\end{array}$ & $\begin{array}{l}48 \\
49\end{array}$ \\
\hline 1 & 8 & 3 & 49 \\
\hline
\end{tabular}


Table V. Datasets of down-go miRs and its targets for interactive viewing of the network using Pajek desktop software.

\begin{tabular}{ll}
\hline Vertices $^{*}$ & \multicolumn{1}{c}{26} \\
\hline 1 & miR-129-5p \\
2 & miR-205 \\
3 & miR-451 \\
4 & KLF12 \\
5 & CREBBP \\
6 & DDX5 \\
7 & DLX2 \\
8 & ELF1 \\
9 & EP300 \\
10 & EREG \\
11 & ESRRG \\
12 & BPTF \\
13 & ILF3 \\
14 & INHBA \\
15 & SMAD1 \\
16 & NR4A2 \\
17 & PLAGL2 \\
18 & MED1 \\
19 & RNF4 \\
20 & SP1 \\
21 & SRF \\
22 & STAT5B \\
23 & UBE2N \\
24 & YWHAH \\
25 & ARID1A \\
26 & RUNX1T1 \\
\hline &
\end{tabular}

\section{Edges $^{*}$}

\begin{tabular}{lr}
1 & 5 \\
1 & 7 \\
1 & 9 \\
1 & 11 \\
1 & 12 \\
1 & 13 \\
1 & 16 \\
1 & 20 \\
1 & 21 \\
1 & 22 \\
1 & 24 \\
1 & 26 \\
2 & 4 \\
2 & 4 \\
2 & 6 \\
2 & 8 \\
2 & 10 \\
2 & 11 \\
2 & 12 \\
2 & 14 \\
2 & 15 \\
2 & 17 \\
2 & 18 \\
2 & 19 \\
2 & 23 \\
\hline
\end{tabular}

inhibitor inhibited the apoptosis rates when compared with miR-205 inhibitor of $\mathrm{NC}(\mathrm{p}=0.041)$ (Fig. $4 \mathrm{C})$ in vitro. It indicated dysregulation of miR-205 impaired the BLBC cell apoptosis.

\section{Discussion}

BLBC is more common in younger patient and related to high histological grade, aggressive clinical course, distant metastasis, poor prognosis, and relatively high mortality rate (41). Owning to its triple-negative phenotype, patients with BLBC are not likely to benefit from endocrine therapies or trastuzumab, but are likely to benefit from systemic chemotherapy (41). Genetic, morphological and IHC features of BLBC were reported, however, there was no universal definition and specific biomarker which could identify those tumors in routine diagnostics (41). Previously studies revealed $\mathrm{miR}$ dysregulation and dysfunction in breast cancer (10-12), and miR-205 was significantly under-expressed in breast tumors compared with matched normal breast tissue (42). In breast cancer cell lines, including MCF-7 and MDA-MB-231, miR-205 expressed lower levels than non-malignant MCF-10A cells (42). Only a few studies which associated with triplenegative breast cancer revealed that miR-205 was directly transactivated by oncosuppressor p53 (43). In our studies, miR-205 was significantly downregulated in BLBC tumor tissues and MDA-MB-468 cell lines.

Each miR is capable of regulating hundreds of proteincoding genes. Previous studies revealed that most miR-205 target genes were Her- $2 / 3$ and ZEB1/2/3 in breast cancer $(42,44)$. Some others studies also identified that miR-205 directly targeted phosphatase and tensin homolog deleted on chromosome ten and interleukin-24 in A549 cells and human KB oral cancer cells (45). miR-205 in cancer is an angel or a devil depending on the specific tumor context and target genes (19). KLF12 played an important role in poorly differentiated gastric cancer progression and negatively regulated human endometrial stromal cell decidualization $(22,23)$. miR-181a played a functionally important role in human endometrial stromal cell decidualization in vitro by inhibiting KLF12 (46). Ectopic expression of miR-205 significantly inhibits proliferation, growth and invasion as well as impairs apoptosis. These findings established the tumor suppressive role of miR-205, which was probably through directly targeting oncogenes such as Her-2/3 and ZEB1/2/3 (42,44). In our studies, miR-205 directly targeted KLF12 3'-UTR in luciferase assays, KLF12 was negatively regulated by miR-205 in expression analysis, overexpression of miR-205 significantly inhibited invasion and promoted apoptosis in functional investigation. Our finds suggested miR-205/KLF12 functioned as tumor suppressor gene/proto-oncogene in BLBC, respectively.

The mechanism of miR-205-KLF12, apoptosis is an interesting question. From the literature reviews, we found that activating protein-2 (AP-2) factors executed important functions during embryonic development and malignant transformation (21). $A P-2 \alpha$ and $A P-2 \gamma$ overexpression in breast cancer cells direct transcriptional activated Her-2 (47) and correlated with regulation of multiple growth factor signaling pathways (21). Specifically, interaction of AP-2 with the c-Myc-Max heterodimer negatively regulated 

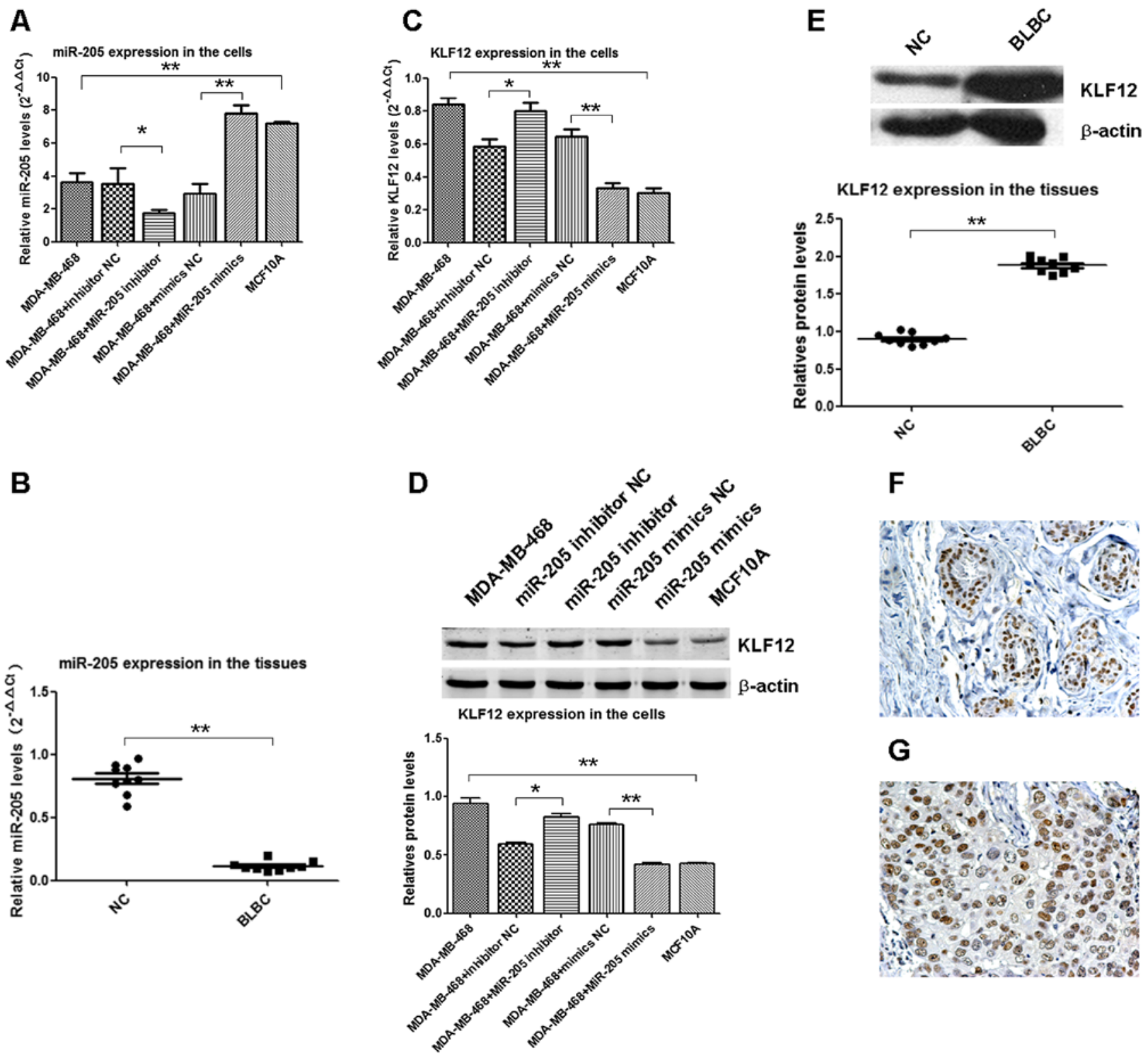

G

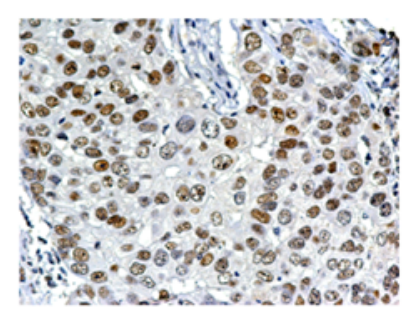

Figure 3. miR-205 and KLF12 expression analysis. (A) miR-205 has significantly lower expression levels in MDA-MB-468 cells than in MCF-10A cells. Knock-up/down of miR-205 mimics/inhibitor and corresponding control, miR-205 was substantially increased/decreased expression levels in cell lines than it in mimics NC/inhibitor NC, respectively. (B) miR-205 has significantly lower expression level in tumor tissues ( $\mathrm{n}=9)$ than in NC (n=9). (C) KLF12 RNA has significantly higher expression levels in MDA-MB-468 cells than in MCF-10A cells. Knock-up/down of miR-205 mimics/inhibitor and corresponding control, KLF12 RNA was substantially decreased/increased in cell lines than in mimics of NC/inhibitor NC, respectively. (D) KLF12 protein was significantly higher in MDA-MB-468 cells than in MCF-10A cells. Knock-up/down of miR-205 mimics/inhibitor and corresponding control, KLF12 protein was substantially decreased/increased in cell lines than it the mimics NC/inhibitor NC, respectively. (E) KLF12 protein expression level was significantly higher in BLBC tumor tissues $(n=9)$ than in NC (n=9). (F) KLF12 showed nuclear positive in the normal ductal inner epithelium and outer myoepithelial cells. (G) KLF12 was diffuse nuclear positive in BLBC tumor cells; ${ }^{*} \mathrm{p}<0.05$ and ${ }^{* *} \mathrm{p}<0.01$.

c-Myc target genes and c-Myc-induced apoptotic cell death, it proposed AP-2 genes were involved in programming cell survival $(48,49)$. The adenoviral oncoprotein E1A activated expression of the endogenous $A P-2 \alpha$ gene. Furthermore, activation of AP- $2 \alpha$ transcription was dependent on the presence of a functional E1A-CtBP1 interaction motif and involves inactivation of the transcriptional silencer AP-2rep (KLF12) by directly interaction with the corepressor CtBP1 (21). Combined with previous studies and our experiments, we speculated that down-regulation of miR-205 negatively regulated KLF12 overexpression, was involved in activation of the transcriptional silencer AP-2rep (KLF12) by direct interaction with the corepressor CtBP1 and inactivation of E1A-CtBP1 interaction motif, led to inactivation of $A P-2 \alpha$ transcription, negatively regulating c-Myc-induced apoptotic cell death and repressing transcriptional activation of Her-2 in BLBC. So, we thought miR-205-KLF12-AP-2 $\alpha$ axis played an important role in negatively regulated c-Myc-induced apoptotic cell death and repressed transcriptional activation of Her- 2 in BLBC. However, further experimental studies are required, and the mechanism of miR-205-KLF12-invasion remains unclear.

In previously studies, the mainly used public miRs target prediction databases facilitate gene-by-gene searches PicTar, TargetScan and miRanda algorithms (34-37). However, its disadvantage was too many target genes to be predicted and many of them were false positive. On the other hand, integra- 

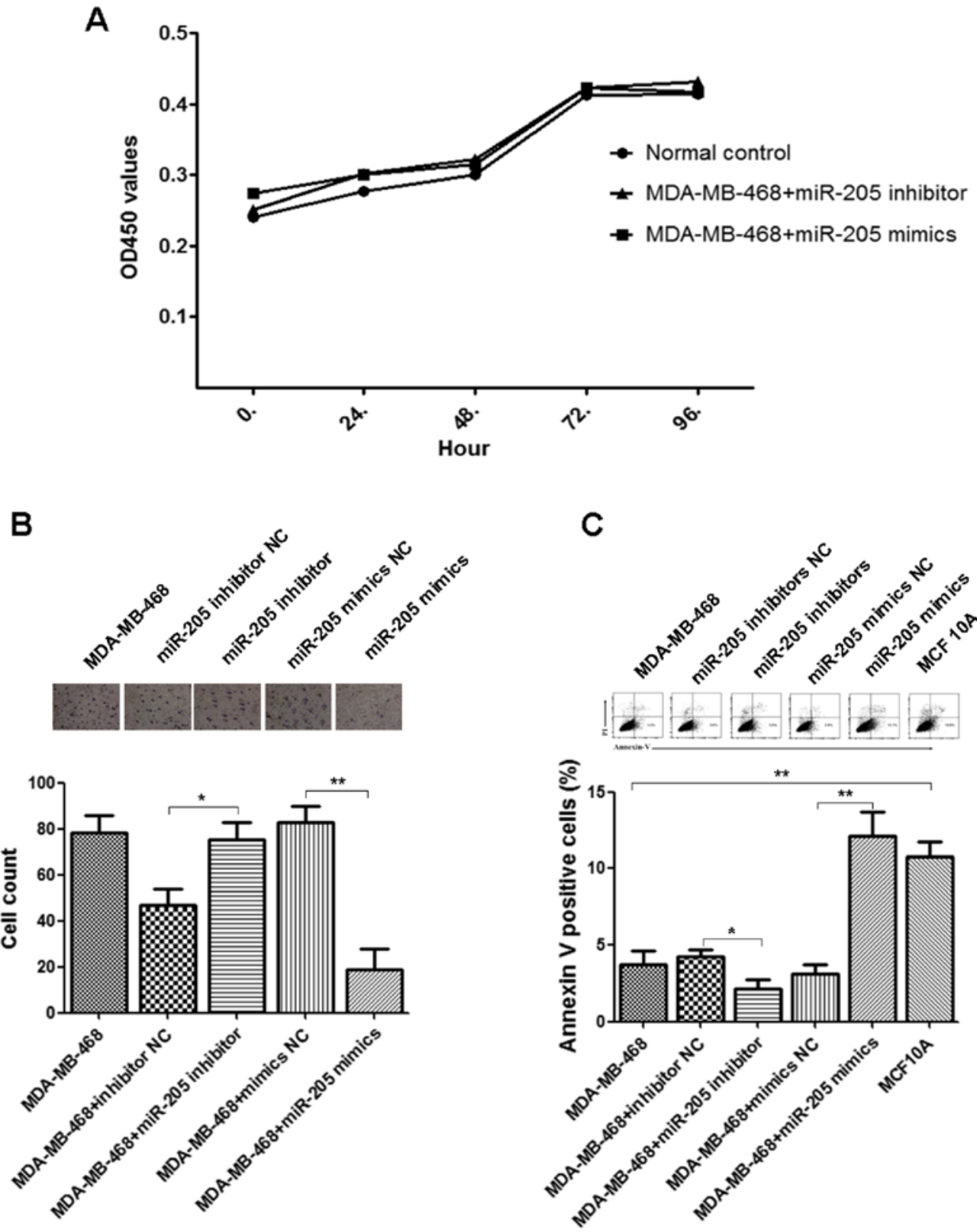

Figure 4. Functional analyses for miR-205. (A) CCK-8 assay was performed to evaluate proliferation ability of BLBC cells. No significant impact on the optical densities was observed after knock-up/down of miR-205 mimics/inhibitor and corresponding control in MDA-MB-468 cells in vitro. (B) Transwell assay was performed to assess invasion ability of BLBC cells. Knock-up of miR-205 by transfection with miR-205 mimics significantly inhibited the transmembrane ability of MDA-MB-468 cells in vitro; knockdown of miR-205 by transfection with miR-205 inhibitor promoted the transmembrane ability of MDA-MB-468 cells in vitro. The number of cells which could invade via the membrane is displayed in the histogram. (C) Flow cytometric analysis was performed to investigate apoptotic rates of BLBC cells. The apoptotic rates of MDA-MB-468 cells were significantly lower level in vitro. Knock-up of miR-205 by transfection with miR-205 mimics significantly induced apoptotic rates in vitro; knockdown of miR-205 by transfection with miR-205 inhibitor inhibited the apoptotic rates. Percentage of positive cells is displayed in the histogram; ${ }^{*} \mathrm{p}<0.05$ and ${ }^{* *} \mathrm{p}<0.01$.

tion of miR-mRNA target predictions with gene expression data on a large scale using these databases currently is cumbersome and time-consuming for researchers. So, we employed the bioinformatics tool including GOs analysis (28-30) and SigTerms (38) in this study. An analysis of significant differences in GOs, which was based on the reported and predicted target genes of these miRs, was developed to highlight whether particular functions were enriched in BLBC. GO organized genes targeted by differential miRs into hierarchical categories based on biological process and then outlined the effects of miRs on BLBC through significantly differences of GOs $(31,38)$. SigTerms for a given target prediction data- base, retrieves all miR-mRNA functional pairs represented by an experimentally derived set of genes. Furthermore, for each miR, the software computed an enrichment statistic for over-representation of predicted targets within the gene set, which could help to implicate roles for specific miRs and miR-regulated genes in the system under study. Currently, the software supported searching of results from PicTar, TargetScan and miRanda algorithms. Gunaratne et al (ref.?) discussed the latest methodologies for determining genomewide miRs and gene expression changes and considered three programs (SigTerms, CORNA and MMIA) to be essential for determining the false positive and negative rates of existing 
algorithms and refining our knowledge on the rules of miRmRNA relationships. The advantage of GOs and SigTerms was the accuracy in miR target prediction, but specific training for researchers was needed.

The expression pattern of KLF12 was less known in tumor tissues. In our studies, KLF12 was diffusely nuclear positive in BLBC tumor tissues, but nuclear positive in the normal ductal inner epithelium and outer myoepithelial cells, respectively. Basal markers (CK14, CK5/6 and EGFR) and myoepithelial markers (smooth muscle actin and p63) were positive in myoepithelial cells, and epithelial markers (epithelial membrane antigen, cytokeratin Cam5.2) were positive in luminal epithelial. So, the double staining characteristics of KLF12 were helpful for the differential diagnosis between benign lesion and invasive ductal carcinoma. It also suggested that KLF12 may function as molecular biomarker for BLBC combination with other biomarkers, but this requires further studies in clinical specimens.

In conclusion, miR-205 is miR-specific in BLBC functioning as tumor suppressor gene through directly targeted and negatively regulated proto-oncogene KLF12. miR-205 dysregulation was involved in invasion and apoptosis in MDA-MB-468 cells in vitro. miR-205 and KLF12 provide potential diagnostic biomarkers and therapeutic approach for BLBC.

\section{Acknowledgements}

The study reported in this publication was funded by grants from the Medical Guide Program of Science and Technology of Shanghai Municipal Science and Technology Commission, Shanghai, China (134119b2800) and the General Program of Shanghai Jinshan District Health and Family Planning Commission, Shanghai, China (JSKJ-KTMS-2014-14).

\section{References}

1. Torre LA, Bray F, Siegel RL, Ferlay J, Lortet-Tieulent J and Jemal A: Global cancer statistics, 2012. CA Cancer J Clin 65 : 87-108, 2015

2. Badve S, Dabbs DJ, Schnitt SJ, Baehner FL, Decker T, Eusebi V, Fox SB, Ichihara S, Jacquemier J, Lakhani SR, et al: Basal-like and triple-negative breast cancers: A critical review with an emphasis on the implications for pathologists and oncologists. Mod Pathol 24: 157-167, 2011

3. Haupt B, Ro JY and Schwartz MR: Basal-like breast carcinoma: A phenotypically distinct entity. Arch Pathol Lab Med 134: 130-133, 2010.

4. Rakha E and Reis-Filho JS: Basal-like breast carcinoma: From expression profiling to routine practice. Arch Pathol Lab Med 133: 860-868, 2009.

5. Silva F, Carvalho S, Milanezi F and Schmitt FC: Basal-like carcinoma of the breast. Acta Med Port 21: 373-378, 2008 (In Portuguese).

6. Su CM, Wang MY, Hong CC, et al: miR-520h is crucial for DAPK2 regulation and breast cancer progression. Oncogene, 2015.

7. Baek D, Villén J, Shin C, Camargo FD, Gygi SP and Bartel DP: The impact of microRNAs on protein output. Nature 455: 64-71, 2008.

8. Schmittgen TD: Regulation of microRNA processing in development, differentiation and cancer. J Cell Mol Med 12: 1811-1819, 2008.

9. Croce CM: Causes and consequences of microRNA dysregulation in cancer. Nat Rev Genet 10: 704-714, 2009.

10. Vilquin P, Donini CF, Villedieu M, Grisard E, Corbo L, Bachelot T, Vendrell JA and Cohen PA: MicroRNA-125b upregulation confers aromatase inhibitor resistance and is a novel marker of poor prognosis in breast cancer. Breast Cancer Res 17: 13, 2015 .
11. Hu Y, Xu K and Yagüe E: miR-218 targets survivin and regulates resistance to chemotherapeutics in breast cancer. Breast Cancer Res Treat 151: 269-280, 2015.

12. Liu R, Liu C, Chen D, Yang WH, Liu X, Liu CG, Dugas CM, Tang F, Zheng P, Liu Y, et al: FOXP3 controls a miR-146/NF- $\kappa \mathrm{B}$ negative feedback loop that inhibits apoptosis in breast cancer cells. Cancer Res 75: 1703-1713, 2015.

13. Zhang G, Hou X, Li Y and Zhao M: MiR-205 inhibits cell apoptosis by targeting phosphatase and tensin homolog deleted on chromosome ten in endometrial cancer Ishikawa cells. BMC Cancer 14: 440, 2014.

14. Iorio MV, Casalini P, Piovan C, Di Leva G, Merlo A, Triulzi T, Ménard S, Croce CM and Tagliabue E: microRNA-205 regulates HER3 in human breast cancer. Cancer Res 69: 2195-2200, 2009.

15. Verdoodt B, Neid M, Vogt M, Kuhn V, Liffers ST, Palisaar RJ, Noldus J, Tannapfel A and Mirmohammadsadegh A: MicroRNA-205, a novel regulator of the anti-apoptotic protein $\mathrm{Bcl} 2$, is downregulated in prostate cancer. Int J Oncol 43: 307-314, 2013.

16. Matsushima $K$, Isomoto $H$, Yamaguchi $N$, Inoue $N$, Machida $H$, Nakayama T, Hayashi T, Kunizaki M, Hidaka S, Nagayasu T, et al: MiRNA-205 modulates cellular invasion and migration via regulating zinc finger E-box binding homeobox 2 expression in esophageal squamous cell carcinoma cells. J Transl Med 9: 30, 2011.

17. Yue X, Wang $P, X u J, Z$, , Y, Sun G, Pang Q and Tao R: MicroRNA-205 functions as a tumor suppressor in human glioblastoma cells by targeting VEGF-A. Oncol Rep 27: 1200-1206, 2012.

18. Chen Z, Tang ZY, He Y, Liu LF, Li DJ and Chen X: miRNA-205 is a candidate tumor suppressor that targets ZEB2 in renal cell carcinoma. Oncol Res Treat 37: 658-664, 2014.

19. Qin AY, Zhang XW, Liu L, Yu JP, Li H, Wang SZ, Ren XB and Cao S: MiR-205 in cancer: An angel or a devil? Eur J Cell Biol 92: 54-60, 2013.

20. Bureau C, Hanoun N, Torrisani J, Vinel JP, Buscail L and Cordelier P: Expression and function of Kruppel like-factors (KLF) in carcinogenesis. Curr Genomics 10: 353-360, 2009.

21. Schuierer M, Hilger-Eversheim K, Dobner T, Bosserhoff AK, Moser M, Turner J, Crossley M and Buettner R: Induction of AP-2alpha expression by adenoviral infection involves inactivation of the AP-2rep transcriptional corepressor CtBP1. J Biol Chem 276: 27944-27949, 2001.

22. Nakamura Y, Migita T, Hosoda F, Okada N, Gotoh M, Arai Y, Fukushima M, Ohki M, Miyata S, Takeuchi K, et al: Kruppel-like factor 12 plays a significant role in poorly differentiated gastric cancer progression. Int J Cancer 125: 1859-1867, 2009.

23. Shen X, Hu Y, Jiang Y, Liu H, Zhu L, Jin X, Shan H, Zhen X, Sun L, Yan G, et al: Krüppel-like factor 12 negatively regulates human endometrial stromal cell decidualization. Biochem Biophys Res Commun 433: 11-17, 2013.

24. Bloom HJ: Complications following radiotherapy of the thorax and abdomen. Proc R Soc Med 52: 495-500, 1959.

25. Elston CW and Ellis IO: Pathological prognostic factors in breast cancer. I. The value of histological grade in breast cancer: Experience from a large study with long-term follow-up. Histopathology 19: 403-410, 1991.

26. Finn RS, Dering J, Ginther C, Wilson CA, Glaspy P, Tchekmedyian N and Slamon DJ: Dasatinib, an orally active small molecule inhibitor of both the src and abl kinases, selectively inhibits growth of basal-type/'triple-negative' breast cancer cell lines growing in vitro. Breast Cancer Res Treat 105: 319-326, 2007.

27. Nielsen TO, Hsu FD, Jensen K, Cheang M, Karaca G, Hu Z, Hernandez-Boussard T, Livasy C, Cowan D, Dressler L, et al: Immunohistochemical and clinical characterization of the basallike subtype of invasive breast carcinoma. Clin Cancer Res 10: 5367-5374, 2004

28. Gene Ontology Consortium: The Gene Ontology (GO) project in 2006. Nucleic Acids Res 34: D322-D326, 2006.

29. Blake JA and Harris MA: The Gene Ontology (GO) project: structured vocabularies for molecular biology and their application to genome and expression analysis. Curr Protoc Bioinformatics Chapter 7: Unit 7.2, 2008.

30. Camon E, Magrane M, Barrell D, Binns D, Fleischmann W, Kersey P, Mulder N, Oinn T, Maslen J, Cox A, et al: The Gene Ontology Annotation (GOA) project: Implementation of GO in SWISS-PROT, TrEMBL, and InterPro. Genome Res 13: 662-672, 2003.

31. Guo CJ, Pan Q, Li DG, Sun H and Liu BW: miR-15b and miR-16 are implicated in activation of the rat hepatic stellate cell: An essential role for apoptosis. J Hepatol 50: 766-778, 2009. 
32. Rajewsky N: microRNA target predictions in animals. Nat Genet 38 (Suppl): S8-S13, 2006.

33. Storey JD and Tibshirani R: Statistical significance for genomewide studies. Proc Natl Acad Sci USA 100: 9440-9445, 2003.

34. Lewis BP, Burge CB and Bartel DP: Conserved seed pairing, often flanked by adenosines, indicates that thousands of human genes are microRNA targets. Cell 120: 15-20, 2005

35. Lewis BP, Shih IH, Jones-Rhoades MW, Bartel DP and Burge CB: Prediction of mammalian microRNA targets. Cell 115: 787-798, 2003.

36. Krek A, Grün D, Poy MN, Wolf R, Rosenberg L, Epstein EJ, MacMenamin P, da Piedade I, Gunsalus KC, Stoffel M, et al: Combinatorial microRNA target predictions. Nat Genet 37: 495-500, 2005

37. John B, Enright AJ, Aravin A, Tuschl T, Sander C and Marks DS: Human microRNA targets. PLoS Biol 2: e363, 2004.

38. Creighton CJ, Nagaraja AK, Hanash SM, Matzuk MM and Gunaratne PH: A bioinformatics tool for linking gene expression profiling results with public databases of microRNA target predictions. RNA 14: 2290-2296, 2008.

39. Shalgi R, Lieber D, Oren M and Pilpel Y: Global and local architecture of the mammalian microRNA-transcription factor regulatory network. PLoS Comput Biol 3: e131, 2007.

40. Livak KJ and Schmittgen TD: Analysis of relative gene expression data using real-time quantitative PCR and the 2(-Delta Delta C(T)) method. Methods 25: 402-408, 2001.

41. Ishihara A, Tsuda H, Kitagawa K, Yoneda M and Shiraishi T: Morphological characteristics of basal-like subtype of breast carcinoma with special reference to cytopathological features. Breast Cancer 16: 179-185, 2009.

42. Wu H and Mo YY: Targeting miR-205 in breast cancer. Expert Opin Ther Targets 13: 1439-1448, 2009.
43. Piovan C, Palmieri D, Di Leva G, Braccioli L, Casalini P, Nuovo G, Tortoreto M, Sasso M, Plantamura I, Triulzi T, et al: Oncosuppressive role of p53-induced miR-205 in triple negative breast cancer. Mol Oncol 6: 458-472, 2012.

44. Wang S, Huang J, Lyu H, Lee CK, Tan J, Wang J and Liu B: Functional cooperation of miR-125a, miR-125b, and miR-205 in entinostat-induced downregulation of erbB2/erbB3 and apoptosis in breast cancer cells. Cell Death Dis 4: e556, 2013.

45. Kim JS, Yu SK, Lee MH, Park MG, Park E, Kim SG, Lee SY, Kim CS, Kim HJ, Chun HS, et al: MicroRNA-205 directly regulates the tumor suppressor, interleukin-24, in human KB oral cancer cells. Mol Cells 35: 17-24, 2013.

46. Zhang Q, Zhang H, Jiang Y, Xue B, Diao Z, Ding L, Zhen X, Sun $\mathrm{H}$, Yan $\mathrm{G}$ and $\mathrm{Hu}$ Y: MicroRNA-181a is involved in the regulation of human endometrial stromal cell decidualization by inhibiting Krüppel-like factor 12. Reprod Biol Endocrinol 13: 23 , 2015.

47. Bosher JM, Williams T and Hurst HC: The developmentally regulated transcription factor AP-2 is involved in c-erbB-2 overexpression in human mammary carcinoma. Proc Natl Acad Sci USA 92: 744-747, 1995

48. Moser M, Pscherer A, Roth C, Becker J, Mücher G, Zerres K, Dixkens C, Weis J, Guay-Woodford L, Buettner R, et al: Enhanced apoptotic cell death of renal epithelial cells in mice lacking transcription factor AP-2beta. Genes Dev 11: 1938-1948, 1997.

49. Gaubatz S, Imhof A, Dosch R, Werner O, Mitchell P, Buettner R and Eilers M: Transcriptional activation by Myc is under negative control by the transcription factor AP-2. EMBO J 14: 1508-1519, 1995 . 